\title{
PENGARANG, KARYA SASTRA DAN PEMBACA
}

\section{Sapardi Djoko Damono}

Dosen Universitas Indonesia Jakarta.

\begin{abstract}
A Literary work doesnot stand in its isolation. It is created among the reality of human life. The same is true of the author; in creating a literary work, he cannot separate he himself form the reality of his envirmment. That is way, there should be message in every literary work. In other word of literary work is not free from conviction, tendency and the author's with. In reading a literary work, there shred be a connection between the author, literas work uselfrand the reader. This relationship causes literary work be meaningful and dinamic.
\end{abstract}

Key words

Author, Literary, Reader

\section{Pendahuluan}

Kebanyakan pembicaraan mengenai telaah sastra diawali dengan usaha untuk menjelaskan pengertian sastra itu apa; karangan ini pun tidak menyimpang dari kebisaan tersebut. Usaha ini penting, sebab kita harus mengetahui apa yang kita telaah. Sering dalam bertukar pendapat mengenai sastra terjadi perbedaan hanya karena sebenarnya konsep yang dipergunakan masing-masing tidak sama. Perbedaan konsep mengenai sastra inilah yang telah menjadikan kebanyakan pembicaraan sastra terasa tak berujung pangkal. Meskipun juga diakui bahwa usaha untuk menetapkan perbedaan antara sastra dan bukan sastra tidak terlalu memuaskan, malah mungkin bisa dikatakan tidak 
akan pernah memuaskan semua pihak; bagaimanapun usaha itu perlu dilakukan.

Dalam karangan ini, saya memusatkan perhatian pada sastra tulis, meskipun dalam kenyataannya sastra lisan merupakan bahan yang tidak kalah pentingnya untuk ditelaah, terutama di negeri yang khazanah sastra tulisnya sangat beragam, seperti negeri kita ini. Dalam pengertian lama sastra bisa dibicarakan berdasarkan berdasarkan dua hal: isi, yakni yang terkandung di dalamnya, dan bentuk, yakni cara menyampaikan kandungan itu. Pandangan semacam itu mungkin sekarang sudah ditinggalkan oleh munculnya berbagai teori mutakhir yang beranggapan bahwa dikotomi isi dan bentuk itu tak sah lagi sebab keduanya tidak bisa dipisahkan. Namun, dalam kesempatan ini, pembicaraan kita sebaiknya didasarkan atas pemisahan isi dan bentuk itu (Eangleton, 1983:110).

\section{Karya Sastra}

Ditinjau dari segi isi, sastra biasanya dikatakan sebagai karangan yang tidak mengandung fakta tetapi fiksi. Sastra dibedakan dari berbagai jenis tulisan lain seperti, berita, laporan perjalanan, sejarah, biografi, dan tesis, sebab jenis-jenis tulisan itu menyampaikan informasi yang berupa fakta. Dengan demikian menurut pandangan ini, jelas bahwa sastra adalah segala jenis karangan yang berisi dunia khayalan manusia, yang tidak bisa begitu saja dihubung-hubungkan dengan kenyataan. Konsekuensi pandangan ini adalah bahwa dunia diciptakan sastrawan dalam puisi, novel, dan drama merupakan hasil khayalan yang harus dipisahkan dari dunia nyata, yakni dunia yang kita hayati sehari-hari ini.

Untuk menjelaskannya, saya akan mengambil novel karya Mh. Roesli, Siti Nurbaya (1922), sebagai contoh. Tokoh-tokoh dalam novel tersebut, seperti Siti Nurbaya, Samsul Bahri, dan Datuk Maringgih harus kita anggap sebagai tokoh-tokoh khayalan yang sepenuhnya merupakan ciptaan pengarang. Mungkin sekali diPadang pernah hidup orang-orang dengan nama serupa, namun mereka itu jelas tidak terlibat 
dalam serentetan peristiwa seperti yang digambarkan pengarang dalam novelnya. Harus dicatat bahwa jika kita berada di Padang, ada kemungkinan orang setempat akan menunjukkan suatu tempat yang dikatakannya sebagi kuburan Siti Nurbaya. Hal ini jelas menunjukkan bahwa bagi sementara orang, batas antara fakta dan fiksi tidak jelas, atau bahkan tidak pernah ada.

Berdasarkan pandangan ini, kita pun selanjutnya bisa berpegang pada pendirian bahwa latar novel itu, yakni waktu dan tempat kejadian, juga sepenuhnya fiksi; kota Padang, rumah Datuk Maringgih, dan zaman kolonial merupakan hasil rekaan pengarang saja, dan tentunya tidak bisa juga dikaitkan dengan kenyataan. Pasar Ambacang, delman dan belebas yang disebut-sebut dalam novel itu juga harap dianggap fiksi saja. Konsekuensi pandangan ini adalah bahwa nilai-nilai dan kaidah-kaidah yang ada dalam dunia itu tidak usah dikait-kaitkan dengan nilai-nilai dan kaidah-kaidah yang kita yakini atau kita tolak. Jadi, seandainya ada hal-hal dalam novel tersebut yang kita anggap tidak sesuai dengan dunia nyata, seharusnya kita tidak usah repot mempermasalahkannya. Seandainya menurut kita ada hal yang tidak benar dalam penggambaran kota Padang, kita tidak perlu ribut, sebab Padang yang rekaan itu tentunya tidak sama dengan Padang yang ada dalam kenyataan; hanya kebetulan saja nama yang dipilih pengarang sama. Juga, seandainya ada yang menurut kita tidak logis dalam penggambaran mengenai perkembangan psikologis tokoh Siti Nurbaya, kita pun tidak usah mengritiknya berdasarkan teori ilmu jiwa, karena ilmu itu hanya bisa diterapkan pada manusia nyata, dan tidak pada manusia rekaan.

Jika kita berpegang teguh pada pandangan ini, tentunya tidak usah ada ribut-ribut mengenai cerita pendek "Langit Makin Mendung" karya Ki Pandjikusmin, Satanic Verses karya Salman Rushdie, dan The Last Temptantion of Christ karya Nikos Kazanzakis, sebab jelas hal itu merupakan pencampuradukkan fiksi dan fakta. Umat Islam dan Kristen melancarkan protes terhadap karya-karya tersebut, sebab Muhammad dan Isa, dua utusan Tuhan itu telah diejek atau direndahkan derajatnya. Kaum yang beragama Islam dan Kristen tidak bisa menerima 
pandangan bahwa sastra adalah fiksi belaka, bahwa Nabi Muhammad dan Nabi Isa yang ada dalam karangan-karangan tersebut adalah semata-mata hasil khayalan pengarang dan tidak ada kaitannya sama sekali dengan kenyataan. Bagi umat beragama Nabi tetap harus dihadapi sebagai nabi tidak peduli dalam fiksi atau kenyatan seharihari.

Tetapi sebenarnya kesulitan yang bisa muncul dalam pandangan ini tidak terutama berasal dari kecenderungan kita untuk mencampuradukkan fakta dan fiksi, tetapi dari kenyataan bahwa ternyata banyak karya sastra yang benar-benar mengandung fakta. Sejarah memang bukan karya sastra, meskipun bisa saja ditulis dengan bahasa yang penuh dengan metafora, tetapi bagaimana halnya novel sejarah, salah satu subgenre penting dalam sastra? Novel sejarah adalah suatu subgenre yang memanfaatkan peristiwa dari tokoh sejarah sebagai bahan utamanya. Dalam novel Mangunwijaya yang berjudul "Burung-burung Manyar, misalnya, kita mendapatkan tokoh-tokoh Sukarno dan Sahrir, apakah kedua tokoh sejarah itu kita anggap sepenuhnya hasil rekaan pengarang, meskipun mungkin kita tidak akan menganggap karya Mangunwijaya itu sebagai novel sejarah? Dan bagaimana pula halnya dengan novel sejarah semacam Surapati karya N. St Iskandar? Apakah tokoh Surapati dalam novel itu kita anggap sebagai ciptaan pengarang saja, padahal dalam sejarah kita tokoh itu memang benar-benar pernah ada?

Novel sejarah bukan satu-satunya subgenre yang menyuilitkan pandangan ini; dalam sastra, kita juga mengenal novel biografi. Apakah tokoh dan peristiwa, yang memang pernah terjadi, dalam novel jenis ini kita anggap sebagi hasil rekaan saja? Seorang penelaah sastra tentunya diiharapkan memilliki pemahaman yang baik atas teori sastra, pangalaman, dan pengetahuan yang luas --setidaknya lebih dari pembaca awam. Hal yang disebut terakhir itulah yang berkaitan erat dengan prinsip fiksionalitas dan ekstrinsikalitas dalam telaah sastra. Di satu sisi ia harus tetap bertahan pada landasan bahwa yang ditelaahnya semata-mata fiksi, di sisi lain ia menyadari bahwa dalam dunia fiksi yang ditelaahnya itu ternyata terdapat fakta. Jika dalam kegiatan telaah 
sastra kita harus menyertakan penilaian, kedua prinsip itulah yang kemungkinan besar bisa menyulitkan pelaksanaan kerjanya. Kesulitan -kalau tidak boleh dinamakan ketidakmungkinan-- dalam usaha untuk sepenuhnya memisahkan fiksi dan fakta inilah yang menyebabkan teori ini harus dipertimbangkan kembali.

Nah, jika kita tidak mempersoalkan apa yang dikandung sastra, dalam arti kita tidak perduli apakah isinya fakta atau fiksi, mungkin sastra bisa dibedakan dari jenis karangan lain berdasarkan bentuknya, yakni cara mengungkapkan kandungan itu. Sastra adalah karya seni yang menggunakan bahasa sebagai medium; kita boleh saja mengikuti pandangan yang menyatakan bahwa sastra adalah rangkaian kata nan indah, tetapi juga harus menerima pandangan bahwa sastra merupakan hasil usaha sastrawan dalam membengkokkan, membelokkan, dan bahkan merusak bahasa --yang merupakan konsekuensi dari poetic license, hak istimewa sastrawan dalam menggunakan mediumnya, yakni bahasa. Berdasarkan pandangan ini yang kemudian dituntut dari sastra adalah orisinalitas dalam penggunaan bahasa.

Penggunaan bahasa secara aneh, tidak wajar, dan asing merupakan ciri utama sastra. Puisi Amir Hamzah, Chairil Anwar, dan Sutarji Calzoum Bachri, misalnya, dianggap karya sastra karena menunjukkan penggunaan bahasa yang segar --antara lain sebagai akibat dari "perusakan" bahasa. Bahasa yang mereka pergunakan itu relatif mudah dibedakan dari bahasa yang kita pakai sehari-hari maupun dalam karangan jenis lain seperti berita, skripsi, dan laporan penelitian. Setidaknya kita boleh mengatakan bahwa bahasa sastra cenderung metaforis, sedangkan bahasa skripsi dituntut untuk menghindari metafor agar pengertian yang disampaikannya tidak bermakna ganda. Dalam percakapan biasa di kedai kopi atau di kamar tamu, orang tentu akan terheran-heran seandainya kita tiba-tiba mengucapkan "Habis kikis/Segala cintaku hilang terbang", meskipun mungkin bahasa yang dipergunakan Amir Hamzah dalam sajak itu belum begitu "rusak" jika dibandingkan dengan karya Sutardji Calzoum Bachri dalam kumpulan sajak $O$. 
Jika penyimpangan bahasa merupakan sarat utama sastra, masalah lain akan muncul yakni kita juga menerima graffiti --yakni ungkapan atau kalimat atau kata yang sering dicoretkan di dindingdinding kamar mandi umum dan tembok-tembok sekolah-- sebagai karya sastra. Iklan pun harus diterima sebagai karya sastra, sebab ditulis dalam bahasa yang tidak jarang "menyimpang" dan memberi kesan yang mendalam. Bahkan jika kita menyinggung orisinalitas pemakaian bahasa sebagai nilai utama dalam sastra, tentu ada graffiti atau iklan yang melampaui puisi karya Rendra atau Gunawan Mohammad. Bahkan dalam perkembangan puisi kita, beberapa penyair yang menyadari pentingnya cara pengucapan telah menciptakan puisi kongkrit dan puisi mbeling, dua subgenre yang tidak jarang hasilhasilnya sulit diterima sebagai karya sastra -sebab antara lain memberi kesan main-main atau tidak mempergunakan bahasa sebagai mediumnya.

Perhatian pada pengucapan sastra yang dibedakan dari bahasa sehari-hari menyulitkan kita juga dalam menghadapi bahasa yang diperlukan dalam novel. Tentu hanya sangat sedikit novelis yang tujuannya hanya "merusak" bahasa, bahkan tidak bisa dikatakan bahwa sebagian besar bahasa dalam novel itu metaforis. Bahkan lagi, sebenarnya kesulitan itu bisa muncul dalam bahasa puisi; hanya kesepakatan diantara kita saja yang menganggap baris-baris berikut ini adalah sebuah sajak: "Selama ini kita selalu / ragu-ragu / /dan berkata: / Dua tambah dua / mudah-mudahan sama dengan empat". Rangkaian kata itu adalah sajak Taufiq Ismail yang berjudul "Aritmetik Sederhana"

Persoalan dan kesulitan itu tentu tidak usah membuat kita menyerah dengan mengatakan bahwa tidak ada batasan yang pasti untuk sastra. Kita bisa mengikluti usul yang menyatakan bahwa sastra adalah segala sesuatu yang dalam masyarakat tertentu pada masa tertentu dianggap sebagai sastra. Pandangan ini dilandasi kenyataan bahwa sastra bukanlah sesuatu yang berdiri sendiri, terpisah dari masyarakat yang melahirkan dan menikmatinya. Sastra mempunyai kedudukan, peran, dan kegunaan dalam masyarakat --dan itu semua senantiasa mengalami pergeseran dari waktu ke waktu dan perbedaan 
antara satu masyarakat dengan masyarakat lain. Bagi masyarakat tertentu di Jawa pada abad lampau misalnya, yang dinamakan sasrtra adalah karya seperti ditulis oleh Ronggo Warsito, yakni yang sangat terikat pada kaidah penulisan dan mengandung nilai pendidikan serta gagasan luhur. Sampai dengan tahun 50-an, masih banyak budayawan jawa yang merendahkan cerita pendek dan puisi modern jawa sebagai karangan yang tak karuan bahasanya dan tidak mendidik, oleh karenanya tidak bisa dianggap sebagai sastra. Sebaliknya sekarang tentunya sebagian sastrawan muda jawa beranggapan tembang yang tidak jarang disisipkan dalam penyebar semangat atau Joyoboyo sebagi hasil ketrampilan saja, dan bukan sastra. Mungkin sekali sekarang ini kita beranggapan bahwa sastra tidak harus mendidik, menghibur saja pun boleh, bahkan main-main pun diperkenankan. Tentu tidak bisa dikatakan bahwa pada zaman dahulu tidak ada yang menghibur atau main-main dengan bahasa tetapi sangat mungkin hasilnya tidak dianggap sebagai sastra.

\section{Sastrawan/Pengarang}

Sastra tidak jatuh begitu saja dari langit sana; ia dihasilkan oleh sastrawan dan dimaksudkan untuk dibaca orang lain. Tentunya sastra juga mempunyai asal-usul; ia berasal dari masyarakat yang mencakup si sastrawan sebagai anggotanya. Lebih lanjut lagi --terutama oleh pembacanya- sastra juga dikait-kaitkan dengan kenyataan. Karena ilmu sastra bertugas menafsirkan makna yang ada dalam karya sastra, tersedia berbagai cara yang bisa ditempuh untuk maksud tersebut. Secara garis besar, ada dua pendekatan yang lazim dilaksanakan, yakni pendekatan intrinsik dan pendekatan ekstrinsik (Wellek, 1985:87). pada dasarnya, pendekatan intrinsik menganggap karya sastra sebagai keutuhan yang bisa berdiri sendiri, yang penafsirannya tidak tergantung pada faktor-faktor di luar karya sastra itu sendiri. Sebaliknya pendekatan ekstrinsik menggarisbawahi pentingnya faktor-faktor di luar karya sastra untuk membantu penafsirannya. Faktor-faktor luar itu 
bisa berupa pengarang, zaman, masyarakat, dan kenyataan yang telah menghasilkannya.

Dalam pengertian terbatas, menafsirkan karya sastra berarti menjelaskan makna bahasanya dengan cara uraian, parafrase, dan komentar. Tafsir atau interpretasi semacam itu biasanya memusatkan perhatian pada bagian-bagian yang sulit atau "gelap", dalam pengertian bermakna ganda, dalam suatu karya sastra. Dalam pengertian yang lebih luas, menafsirkan karya sastra berarti menjelaskan makna keseluruhan karya seni yang mediumnya bahasa. Dalam pengertian ini, interpretasi menyangkut pengungkapan genre karya sastra itu sendiri, unsur-unsur, stuktur, tema, dan dampaknya. Langkah-langkah dalam penafsiran ini erat kaitannya dengan proses pendekatan yang disebut Hermeneutika. Hermeneutika semula berarti interpretasi yang berkaitan dengan Alkitab, yakni proses penyusunan kaidah yang menentukan kesahihan pembacaan Alkitab serta penjelasan mengenai penerapan makna yang diungkapkan dalam teks keagamaan tersebut.

Sejak abad ke-19 terjadi pergeseran dan perluasan makna Hermeneutika, yakni teori umum mengenai penafsiran, yang pada dasarnya menyagkut penyusunan prosedur dan prinsip-prinsip dalam mendapatkan makna sekalian teks tertulis yang mencakup hukum dan sastra. Dalam perkembangan selanjutnya Hermeneutika dirancang khusus sebagai kiat pemahaman untuk mendasari interpretasi human sciences atau ilmu-ilmu kemanusian, yakni sastra, ilmu sosial, dan humaniora yang memang dibedakan dari natural sciences atau ilmu alam. Perbedaan antara keduanya adalah bahwa ilmu alam pada dasarnya bertugas "menjelaskan" gejala-gejala alam yang menjadi obyek penelitian, sedangkan ilmu kemanusiaan bertugas "memahami" obyek yang diteliti.

Dalam kaitannya dengan karya sastra, cara pemahamannya merupakan lingkaran Hermeneutika. Karya sastra adalah jenis kesenian yang mempergunkaan bahasa sebagai medium; untuk memahami makna-makna dalam unit-unit kebahasaannya, kita harus mendekatinya berdasarkan makna keseluruhannya terlebih dahulu. Namun, makna 
keseluruhan itu baru bisa diungkapkan jika kita sudah memahami bagian-bagiannya. Dengan demikian, proses pemahaman itu bergesergeser dari upaya memahami makna secara keseluruhan dan makna bagian-bagiannya. Prosedur ini tampaknya semacam lingkaran setan yang tidak ada ujung pangkalnya namun jika kita terus menerus mengusahakannya maka jalinan pemahaman keseluruhan dan pemahaman bagian-bagian itu akan membawa kita ke arah interpretasi yang sahih.

Munculnya madhab kritik baru (New Criticism) pada tahun 40-an di Amerika Serikat pada hakekatnya merupakan bukti menonjolnya minat terhadap Hermeneutika, yang antara lain menekankan bahwa tugas kritik sastra adalah mengungkapkan makna verbal karya sastra. Mashab kritik baru itu sebenarnya sangat luas jangkauannya dan tidak bisa begitu saja dianggap sebagai semacam gerakan yang dicetuskan bersama-sama oleh para pengikutnya, namun ada beberapa prinsip dasar yang bisa dijadikan pegangan. Di bagian awal karangan ini sudah dijelaskan mengenai usaha memberi batasan-batasan sastra berdasarkan bentuk dan isi; tampaknya kritik baru cenderung untuk membatasi sastra berdasarkan bentuknya. Prinsip-prinsip berikut ini akan lebih menjelaskan posisinya (Richard, 1924:135).

Pertama, sastra harus diperlakukan sebagai sastra dan bukan yang lainnya. Maksud prinsip pertama ini tentunya jelas, yakni bahwa tidak semestinya kita memperlakukan dan menghadapi karya sastra sebagai kitab suci, sumber sejarah, informasi mengenai cuaca, panduan peristiwa, dan sebagainya. Sastra seharusnya diperlakukan sebagai obyek yang bebas dan bisa memenuhi kebutuhan sendiri. Karya sastra itu otonom dan adanya adalah demi dirinya sendiri; artinya maknanya tidak tergantung pada apapun yang berada di luarnya. Dua konsep penting dalam mashab ini adalah intentional fallacy dan affective fallacy. Fallacy adalah gagasan yang diyakini kebenarannya oleh banyak orang, tetapi yang sebenarnya keliru sebab didasarkan pada keterangan atau cara berpikir yang salah. Anggapan keliru itu yang pertama itu dikaitkan dengan kebisaaan kita dalam menghubung-hubungkan karya sastra dengan maksud pengarang dalam menulis karyanya, riwayat 
hidupnya, keadaan masyarakat ketika karya itu dihasilkan. Sebagai sekedar contoh, jika kita membaca sajak Chairil Anwar yang berjudul "Aku" kita tidak boleh mengkait-kaitkannya dengan maksud penyair menulis sajak itu, tidak diperkenankan menghubungkannya dengan zaman penjajahan Jepang (masa ditulisnya sajak tersebut), diharamkan juga mengukurnya dengan situasi sosial politik yang ada pada zaman penuliasan sajak tersebut, dan sebagainya.

Anggapan keliru yang kedua (affective fallacy) menyangkut kebiasaan kita dalam menghubung-hubungkan karya sastra dengan dampaknya terhadap moral dan jiwa pembaca. Dalam membaca karya sastra kita mempunyai kebiasaan untuk menghubungkan kandungannya dengan pengalaman dan keyakinan kita sendiri. Jika apa yang terkandung dalam karya itu sesuai dengan keyakinan agama kita, misalnya, kita cenderung menyukainya atau menganggapnya bagus. Kita juga suka menjadi terharu membaca karya sastra hanya karena kandungan karya itu mengingatkan kita pada pengalaman kita sendiri. Dalam proses pemahaman, kedua hal tersebut cenderung berpengaruh. Kebisaaan-kebisaaan semacam itu diharamkan oleh mashab ini. Bahkan sejarah dan perkembangan sastra serta "bahan" yang dikandung karya sastra itu pun seharusnya tidak dipergunakan sebagai bahan pertimbangan dalam proses interpretasi.

Prinsip kedua menyangkut prosedur yang penting dalam mashab ini, ialah pembacaan yang teliti. Langkah-langkah utama yang harus ditempuh oleh seorang kritikus, menurut masab ini, adalah uraian yang terperinci dan berhati-hati atas hubungan-hubungan yang rumit antara unsur-unsur yang ada dalam karya sastra terutama yang menyangkut ambiguitas atau ketaksaan. Dalam puisi, misalnya, unsur-unsur seperti rima, metafora, lambang, citra, dan paradoks membentuk jaringan makna. Jaringan tersebut mungkin saja sangat rumit dan menghasilkan makna yang tidak hanya satu atau taksa. Langkah-langkah yang harus diambil bukan sekedar menguraikan unsur-unsur tersebut secara terpisah-pisah, tetapi hubungan-hubungan yang ada antara semua unsur. Uraian ini akan membawa kita ke jaringan makna yang 
terkandung dalam karya sastra, tanpa harus mengaitkannya dengan hal-hal apa pun di luar teks.

Prinsip penting ketiga dalam mashab ini adalah anggapan bahwa pada dasarnya karya sastra itu jenis bahasa khusus yang ciri-cirinya dibedakan dari bahasa ilmiah dan wacana logis. Sejalan dengan prinsip kedua, prinsip ini menggaris-bawahi anggapan bahwa makna karya sastra tidak bisa dipisahkan dari jaringan yang diciptakan oleh unsurunsurnya, yakni majas, lambang, citra dan sebagainya. Ditekankan adanya kesatuan organis antara makna dan jaringan unsur, atau struktur kerja karya sastra. Pemisahan antara keduanya dianggap sebagai penyimpangan. Oleh karenanya parafrase sebuah puisi tanpa usaha penguraian unsur-unsurnya, misalnya, sangat tidak dianjurkan. Kita bisa saja membuat ringkasan disertasi atau berita di koran tanpa merusak maknanya, namun langkah itu tidak mungkin dilakukan atas karya sastra.

Keempat, umumnya kritikus mashab ini beranggapan unsurunsur terpenting dalam karya sastra adalah kata, citraan, dan lambang. Dalam kenyataannya mereka lebih banyak membicarakan puisi, mungkin karena ringkas, tetapi pada dasarnya bagi mereka perbedaan antara puisi, novel, dan drama tidak begitu penting. Dalam drama dan novel unsur-unsur yang harus dikaji tetap saja kata, citraan, dan lambang --bukan terutama tokoh, alur, dan tema. Sering sekali disebutsebut bahwa unsur-unsur kebahasaan disusun di seputar tema pokok dengan maksud untuk menimbulkan tiga hal penting yakni ketegangan, ironi, dan paradoks dalam struktur. Ketiga konsep penting dalam kritik baru itu merupakan "penyelesaian" atau "kesimpulan" dari kecenderungan pikiran dan dorongan-dorongan kejiwaan yang berbeda-beda, atau "keseimbangan" yang muncul dari kekuatankekuatan yang bertentang-tentangan. Dengan demikiain tidak peduli apakah karya sastra itu memiliki tokoh atau alur, bentuknya berupa struktur makna.

\section{Pembaca dan Kritik Karya Sastra}


Dalam perkembangan selanjutnya, kecenderungan untuk secara ketat mengharamkan faktor-faktor ekstrinsik itu menjadi longgar. Jika kritik baru jelas-jelas mengharamkan intertpretasi berdasarkan pertimbangan faktor-faktor luar, termasuk keadaan kejiwaan pengarang, maka pada akhir tahun 60-an muncul pandangan bahwa suatu teks itu memiliki makna yang sama dengan yang diniatkan prengarangnya (Hirsch, 1967). Niat verbal pengarang itu pasti dan tidak berubah sepanjang masa, dan bisa dipahami oleh setiap pembaca. Hal itu tidak berarti bahwa niat verbal itu mencakup seluruh kesadaran jiwa pengarang pada waktu itu menulis, tetapi hanya segi yang terungkapkan dalam kata-kata dengan memanfaatkan potensi yang ada dalam konvensi dan kaidah kebahasaan yang tersedia. Jika suatu teks sama sekali dipisahkan dari yang diniatkan pengarangnya, maka maknanya akan selamanya tak pasti; dengan kata lain bisa timbul perbedaan-perbedaan makna yang tak terbatas. Kita bisa mencapai interpretasi yang pasti dengan menggunakan logika pembenaran, yang dilaksanakan untuk mencapai makna yang diniatkan pengarang. Proses interpretasi yang bisa dilakukan dengan pendekatan hermeneutika ini tidak hanya dengan mengadu kepada kaidah-kaidah umum bahasa, tetapi juga segala hal lain yang tercantum maupun yang tak tercantum dalam teks, yakni segi-segi yang berkaitan pandangan dan sikap hidup pengarang. Acuan yang berada di luar teks itu mencakup lingkungan budaya pengarang, kesan-kesan pribadinya dan konvensi-konvensi sastra yang ada, yang bisa dipergunakannya dalam menyusun karyanya.

Dalam pandangan tersebut, ada perbedaan hakiki antara makna verbal dan arti suatu karya sastra; Hirsch mempergunakan istilah verbal meaning dan significance. Makna verbal suatu teks itu tetap dan tak berubah-ubah dan merupakan urusan hermeneutika. Jika kita menghubungkan makna verbal suatu teks dengan berbagai hal lain seperti keadaan, kepercayaan, atau tanggapan orang seorang muncullah arti teks itu. Arti suatu teks bisa juga muncul dengan mengaitkan makna verbalnya dengan lingkungan budaya zaman, keadaan masyarakat, nilai-nilai, dan sebagainya. Jelaslah bahwa dengan demikian arti suatu 
teks itu selalu berubah-ubah; dan justru itulah yang meyebabkannya bisa hidup terus bagi barbagai jenis pembaca dan berbagai zaman. Sebagai sekedar contoh meskipun makna verbal bait tembang "amenangi jaman edan" tidak berubah, bait itu bisa berarti bagi masingmasing kita jika dihubungkan dengan nilai-nilai, situasi sosial, dan keyakinan yang ada di sekitar kita. Jika urusan hermeneutika adalah makna verbal, maka memunculkan arti karya sastra itu merupakan tugas kritik sastra.

Ada jalur lain dalam pendekatan hermeneutika yang menekankan pentingkanya pembaca dalam menentukan makna karya sastra (Gadamer, 1975). Jalur ini mengandaikan adanya dialog antara teks dan pembaca dalam proses interpretasi. Dalam membaca suatu teks, mau tidak mau pembaca menyertakan apa yang disebut prapemahaman yang ditentukan oleh pandangan pribadi dan pada saat tertentu. Sama sekali berbeda dengan prinsip Kritik Baru, sebagai subyek si pembaca tidak perlu menguraikan teks yang dihadapinya itu sebagai obyek yang otonom. Karena mendasarkan diri pada anggapan bahwa membaca karya sastra adalah membuat dialog dengan karya sastra, maka yang seharusnya dilakukan pembaca sebagai subyek adalah mengajukan serangkaian pertanyaan kepada teks yang diandaikan sebagai lawan bicara; dengan demikian terjadi dialog antara "aku" dan "kau", antara pembaca dan teks. Dalam proses itu pembaca harus bersikap terbuka untuk menerima jawaban-jawaban dari teks berdasarkan unsur-unsur kebahasaan yang ada di dalamnya- yang bisa berupa pertanyaan-pertanyaan yang justru diajukan pembaca kepada teks. Dengan demikian, memahami makna suatu teks berarti suatu kegiatan yang menghasilkan gabungan pandangan-pandangan, yakni pandangan yang dimaksudkan oleh pembaca ke dalam teks dan pandangan yang diserap dari teks oleh pembaca. Dengan proses pemahaman semacam itu, jelas bahwa kita tidak akan sampai pada kaidah-kaidah yang bisa mendasari upaya mencapai interpretasi yang "benar". Yang diajukan oleh Gadamer itu adalah sekedar untuk menggambarkan bagaimana kita bisa berhasil dalam menafsirkan suatu teks. 
Perhatian terhadap pentingnya pembaca dalam menghasilkan makna dari suatu teks digarisbawahi oleh Kritik Tanggapan-Pembaca (Iser, 1974, Holland, 1968). Jika sebelumnya yang menjadi perhatian utama kritik sastra ada teks sastra sebagai suatu stuktur makna, maka Kritik Tanggapan Pembaca ini menekankan utamanya tanggapan pembaca terhadap teks. Dengan demikian yang dipentingkan adalah kegiatan yang ada dalam benak pembaca, bukan unsur-unsur yang ada dalam karya sastra itu seperti alur, tokoh, dan cara pengucapannya. Jelaslah bahwa kritik ini meyakini bahwa makna suatu teks samatamata merupakan hasil atau ciptaan si pembaca masing-masing. Karena masing-masing pembaca memiliki keyakinan, pengalaman, dan nilainilai yang berbeda-beda -ditambah lagi dengan kenyataan bahwa situasi pada saat membaca itu bisa besar pengaruhnya terhadap pembaca-- maka tidak akan pernah ada makna "benar" yang tunggal, baik yang menyangkut unsur-unsur kebahasaannya maupun keseluruhan teks.

\section{Penutup}

Yang telah saya bicarakan adalah sebagian sangat kecil saja dari berbagai landasan yang bisa dipergunakan untuk mengambil langkahlangkah dalam telaah sastra. Landasan-landasan itu terutama menyangkut hubungan-hubungan antara pengarang, teks, dan pembaca. Kita semua tentu maklum bahwa masih banyak landasan yang bisa dipergunakan untuk memulai langkah-langkah kita terutama sekali yang berkaitan dengan hubungan-hubungan yang ada antara teks dan faktor-faktor di luarnya seperti masyarakat dan kenyataan seharihari. Perlu buru-buru saya tambahkan bahwa kita pada dasarnya bisa mempergunakan landasan-landasan itu -yang mana saja- asal sesuai dengan tujuan yang ingin kita capai. Sebenarnya, dalam setiap penelitian yang perlu dipertimbangkan masak-masak adalah tujuannya, karena tujuan itulah yang akan membimbing kita dalam menentukan pendekatan yang kita pergunakan. Jika dipahami dengan baik dan dilaksanakan dengan taat azas, landasan-landasan tersebut bisa 
menghasilkan telaah-telaah yang bermanfaat bagi perkembangan ilmu sastra dan, mungkin, juga bagi perkembangan sastra itu sendiri. $\square$

\section{DAFTAR PUSTAKA}

Eangleton, Terry. 1983. Literary Theory: An Introduction. Oxford.

Gadamer, H.G. 1975. Truth and Method. Chicago.

Hirsch, A.D. 1967. Validity of Interpretation. Chicago.

Holland, Norman. 1968. The Dynamic of Literary. 
Iser, Wolfgang. 1974. The Implied Reader.

Richard, I.A. 1924. Principle of Literary Criticsm. Oxford.

Wellek, Rene dan Austin Wereen. 1985. Teori Kesastraan, Terjemahan. Jakarta: Gramedia. 